\title{
INTEGRATION OF ISLAM AND LOCAL CULTURE: Tandhe' in Madura
}

\author{
Mohammad Hidayaturrahman \\ Fakultas Ilmu Sosial dan Ilmu Politik Universitas Wiraraja \\ J1. Raya Sumenep-Pamekasan KM. 05 Patean, Sumenep, Jawa Timur, 69451 \\ e-mail: hidayatsahabatkita2016@gmail.com
}

\begin{abstract}
Religion with culture often has a collision. But in Madura, between religion and culture can walk together. This research analyzes how the integration between local culture in Madura especially tandhe' culture with Islam, as well as what role local actors in realizing a harmonious life. The theory used in this research is the theory of cultural integration of Emile Durkheim. This research method using phenomenology, with descriptive qualitative approach. This research was conducted by observation and interview. There is an integration between Muslims and the local culture of tandhe', in the form of presenting a culture of tandhe' in marriage activities conducted in an Islamic way. There is the role of actors in creating a harmonious life between Muslims and the culture of tandhe', ranging from religious leaders, and people involved in tandhe'.
\end{abstract}

\begin{abstract}
Abstrak: Integrasi Islam dengan Budaya Lokal: Tandhe' in Madura. Agama dengan budaya seringkali mengalami benturan. Tetapi di Madura, antara agama dengan budaya bisa berjalan bersama. Penelitian ini menganalisis bagaimana integrasi antara budaya lokal di Madura khususnya budaya tandhe' dengan Islam, serta seperti apa peran aktor lokal dalam mewujudkan kehidupan yang harmonis. Teori yang digunakan dalam penelitian ini adalah teori integrasi budaya Emile Durkheim. Metode penelitian ini menggunakan fenomenologi (phenomenology), dengan pendekatan kualitatif deskriptif. Penelitian ini dilakukan dengan melakukan pengamatan/observasi dan wawancara. Ditemukan adanya integrasi antara kaum Muslim dengan budaya lokal tandhe', dalam bentuk menghadirkan budaya tandhe' dalam kegiatan pernikahan yang dilakukan secara islami. Ada peran para aktor dalam menciptakan kehidupan harmonis antara kaum Muslim dengan budaya tandhe', mulai dari tokoh agama dan orang-orang yang terlibat di dalam tandhe'.
\end{abstract}

Keywords: local culture, integration, harmonious, Madura, tandhe' 
MIQOT Vol. XLII No. 1 Januari-Juni 2018

\section{Introduction}

The Madurese are known to hold strong Islamic teachings. In his life Madurese Muslims are known to be steadfast in carrying out Islamic teachings and religious traditions, both formal and cultural. Madurese people recognize that Islam as a formal teaching is believed and followed in individual and collective life.

According to Misnadin, on the other hand, Madurese is stereotypically known as a society that has a tendency to solve life problems through violent means. The stereotype of Madurese is very strong among non-Madurese people, especially those who have never lived on the island known for their salt and tobacco's potential and production. People outside the Madurese tend to identify Madurese with backwardness, carok, murder, and other acts of violence. ${ }^{1}$

The Madurese community, who are largely hereditary to the families of santri, are known to be obedient to teachers or kiai. The role and function of teachers is more emphasized on the context of morality that is tied to religious life, especially in the aspect of peace and salvation from the burden or suffering in the afterlife. Therefore, the adherence of the Madurese to the kiai is a distinctive cultural feature that is unquestionable.

On the other hand, Madurese are known as traditional Muslim communities with Nahdlatul Ulama (NU) organizations. Madurese society in running religious traditions and life though known hard, but very tolerant to various understandings. This is seen from the trip so far there has never been a case of religious conflicts that occurred in Madura (except the case in Sampang, called the family conflict which later widened into a conflict between religious adherents).

According to Pribadi, there are three important elements of cultural santri (Islamic students who learn Islam and stay in Pondok) attached to Madurese society, namely pesantren, representing elements of traditional Islamic education, Nahdlatul Ulama, representing Islamic organizations, and kiai, representing Islamic figures. These three elements are intertwined and form a complex relationship between Islam and politics as practiced in Madurese society. Until now, although Madurese have experienced a shift in assessing modern education, Islamic organizations and ulama, they still retain the sacred values of religion. This can be proved by the strong influence of pesantren, Nahdlatul Ulama, and kiai in religious and worldly affairs. The Madurese believe that Islamic Shariah is very important and needs to be applied in all aspects of their lives. However, like Islam in other parts of Indonesia, Islam in Madura is also strongly influenced by Sufism and local culture. ${ }^{2}$

${ }^{1}$ Misnadin, "Nilai-Nilai Luhur Budaya dalam Pepatah-Pepatah Madura: Positive Cultural Values of Madurese Proverbs," in Atavisme: Jurnal Ilmiah Kajian Sastra, Vol. 15, No. 1, 2012, p. 75 .

${ }^{2}$ Y. Pribadi, Religious Networks in Madura: Pesantren, Nahdlatul Ulama, and Kiai as the Core of Santri Culture," in al-Jami'ah: Journal of Islamic Studies, Vol. 51, No. 1, 2013, p. 1-32. 
Religious leaders also practice religious teachings that respect differences, not easy to judge different people, but rather favor the common good. Religious teachings that are practiced more to give good news to the religious people. Religious leaders are closer to the teachings of the saints who combine religious teachings with the cultural traditions that are inherently attached to society.

According to Susanto, in the social hierarchy of the traditional Madura society, kiai is a social elite as well as a religious elite, thus becoming a central figure and plays a vital role in the life of society. Along with the social dynamics of Madura's people who are moving slowly but surely, in proliferation and modernity, kiai function becomes more and more limited, so it is no longer the sole agent of social change or the main actor of social change. In such cases, the kiai leadership is no longer at the religious-paternist-charismatic level, but moves at a rational-participatory level, so that the reorientation of the role of the kiai in the midst of Madura's dynamics is essential. ${ }^{3}$

In the midst of the moderate attitude of the kiai and religious leaders, they expanded a wide range of local arts and cultures in Madura who were often present in a sacred event such as a wedding performed by Muslims in Madura, such as tandhe'. Tandhe' is one of the arts that is almost always presented by families who organize weddings, especially in remote areas of Madura. The presence of tandhe' as a local Madura culture held in the sacred wedding ceremony which is also one of the Sunnah and guidance and Islamic teachings is interesting to be studied. Because during this time there was no rejection of religious figures and kiai in Madura against the presence of tandhe' at the wedding ceremony held.

According to Endy Saputra, staff from CRCS, local religions and cultures have been less interested by researchers. This could be because the tandhe' is seen as a minor and full of negative stereotypes, since Madura and other areas of Java Island are the majority of Muslims. For cases outside of Madura, such as the Java area there have been some scholars who studied tayub (almost the same as tandhe'). The first is Clifford Geertz in his book Religion of Java. Geertz categorizes tayub as part of the abangan tradition. While Robert Heffner in one of his chapters, Javanese Hindu, writes about politics and cultural art, he discusses the tayub in it. Heffner explains that tayub is part of the Hindu ritual and transforms into a popular cultural art.

In rural community studies, villages are envisioned and introduced as social areas with distinctive characteristics of society, such as prioritizing harmonization rather than conflict, adhering to traditional values, possessing a spirit of collectivity, kinship, and other polite or amicable characteristics. The social relations of rural communities are usually based on the strength of the bonds of brotherhood, kinship and psychological bonding of

${ }^{3}$ Edi Susanto, "Kepemimpinan (Kharismatik) Kyai dalam Perspektif Masyarakat Madura," in Karsa: Journal of Social and Islamic Culture, Vol. XI, No. 1, 2007, p. 30-40. 
feelings. Rural social relations reflect group unity based on kinship or lineage. Sometimes the village is inhabited by several groups of relatives or descendants, sometimes also inhabited only by citizens of the same lineage.

The background of a mixture of people or ethnic groups or rural ancestry is driven by efforts to meet the same needs of a group of individuals, and the sense of doom that they can meet the needs of each other's lives. This situation by Cooley called community or local community. According to Cooley, the social identity of the community is (1) group members are physically close to each other; (2) the number of members is small; (3) continuity of relationships among group members; and (4) the familiarity of social relations. ${ }^{4}$

The familiarity of social relations between group members depends on the intensity of direct contact between members. The familiarity of social relations goes hand in hand with the group's homogeneous ideals, and has a direct effect on the sustainability of the common life. If social relationships have been intertwined for so long, then creating social intimacy is itself a goal of rural society.

Thus it is clear that the relationships between individuals as members of the group are not solely based on the existing agreements, rules and behavior patterns that have been created that have been mutually agreed upon. But the most important thing for the longevity of the relationship lies in the high or low sense of loyalty and devotion of each member to the unity of the group organized according to the pattern of behavior and norms that have been recognized together.

According to Koentjaraningrat, for rural communities, the value of solidarity is a common need that is rated higher than individual needs. Koentjacaraningrat also mentioned that solidarity is manifested in the form of public service, mutual cooperation, which is considered a highly commendable in the rural law system. Similarly, the rights of individuals are not clearly and sharply to take precedence. ${ }^{5}$

This research involves researchers to observe in weddings that invite tandhe' in Talango, Batang-Batang, Batu Putih and Dungkek Subdistricts. In addition, interviews were also conducted with cultural, religious, tandhe', midfielders, academics, and tandhe' enthusiasts. This study presents the role of religious leaders in Madura in making Muslims friendly to tandhe' culture. In addition, what are the factors that support the hospitality of Madura tandhe' culture, and what are the challenges and issues that should be answered by religious leaders and tandhe' players as well as the community, so that the tandhe' can still run together to become local wisdom for Muslims in Madura.

According Jonge, during this time, the Madurese are known as a hard, happy killing, p. 138.

${ }^{4}$ Seorjono Soekanto, Sosiologi Suatu Pengantar (Jakarta: RajaGrafindo Persada, 1982),

${ }^{5}$ Koentjaraningrat, Beberapa Pokok Antropologi Sosial (Jakarta: Dian Rakyat, 1967) p. 10. 
irritable, vindictive, intolerant of others, and religious fanatics. While Madurese see themselves as having three basic images, namely modesty, honor, and Islam. ${ }^{6}$

One of the important customs or traditions of Madurese is to uphold politeness. An impolite person is considered insolent, and he gets scorn or insult as a social sanction. Although outsiders often think Madurese are rude, but they uphold the rules of decency and respect the people following it. Modesty includes the knowledge and implementation of customary rules. This custom governs the relationship between generation, rank, and gender, both at the individual and community level.

As explained, that the Madurese prioritize respect and appreciation, let alone to the elderly or the higher social status. Thus, politeness is essential in social life. Madurese do not want to be underestimated, but also do not want to show themselves. Their behavior is influenced by the situation at hand. If the person confronted is arrogant, big-headed, and self-assertive, others will try to be more arrogant than his opponent; he tends not to lose. Conversely, if the person he faces is understated, humbled and respected, he will be humble. Conversely, if he is treated with reckless, the reply will be even heavier; can even lead to bloodshed, especially when his feelings are offended.

The religion of the Madurese is Islam. This religion has permeated and colored their social life patterns. Religion is considered sacred and should be defended as a guide for human life. Islam is one of the qualities that define the Madurese. Consequently, all Madurese are considered Muslims. None of the Madurese converted. This religious symbol is seen in the abantal expression of the shahada, smokeo 'of faith, the apajung of Allah, which describes the Madurese to animate Islam, so insulting Islam is tantamount to offensive self-esteem.

Religion that some people see in the form of texts from the Qur'an and the hadith of Prophet Muhammad and the behavior of the companions justified by the Prophet, considered rigid, and not dynamic. At other times, culture is considered very flexible, dynamic and varied because it is produced from the work and mind of human mind. So that both cannot meet in the teachings and ideology. In fact, in fact religious adherents in this case Islam is also the people who are involved in the culture in which he came and lived. So that between himself and the adherents of Islam cannot be separated by the culture that grows in the community that he is in it.

The study of the religious life in their cultural life is certainly not intended to dictate, let alone negate, religion and culture, because in practice, in social life, both can live together, grow and develop, in their respective positions and roles. Examining how the process of cultural and religious integration in Madura becomes an interesting and important thing. Because then will be able to know how the process of integration, what are the factors that encourage the integration, and what can hamper such integration. In addition, the

${ }^{6}$ Imam Bonjol Juhari, "Ekonomi dan Prestise dalam Budaya Kerapan Sapi di Madura," in Karsa: Journal of Social and Islamic Culture, Vol. 24, No. 2, 2016, p. 186-204. 
role of religious actors and cultural actors at the local level will also show the integration between religion and culture which in turn creates a harmonious life; there is no conflict or clash for the actors.

This research will provide the benefit of important lessons for religious and cultural actors elsewhere to be able to bring a harmonious life even between religions and cultures are not always mutually shared, even in opposite positions. Researchers who conduct research and studies after this can also make this research as one of the references, to be able to be the initial data how religion with culture in Madura can walk together, without any conflict.

This research is conducted to analyze how the process of integration of Islam in Indonesia with local culture in Madura. This research is also intended to analyze the role of local actors, in this case religious leaders in Madura, which consists of kiai, and tandhe' actors in creating cultural integration with religion, so as to create a harmonious life in the marriage which is held in a Islamic.

\section{Method}

The research design chosen in this research is phenomenology with qualitative descriptive approach. Thus, this research is done through direct observation of the object at the time of research conducted by using observations and interviews to the perpetrators. The focus of this research is on the pattern of integration of Islam and tandhe' culture, especially in Islamic marriages. Formulas, processes, inhibiting factors and potentials that could be a driver of integration.

This study aims to observe the real events that occur in the culture of tandhe' at weddings that are held in an Islamic way, usually taking place in various corners of villages and coastal areas in Madura, East Java. Excludes urban areas in Madura. What is observed in this study is related to the data and facts found in the relation and integration of Muslims in Madura East Java, to tandhe' culture which has been connoted not part of Islamic teachings. Thus, this study provides a relatively complete picture of what happened at the time of the study.

The data collection is done by observation/practice done directly by the researcher, to see tandhe' activity, together with the accompanying musical group during the activity at the wedding which was done in a number of places including Talango, Batu Putih, Batang-Batang, and Dungkek. In addition to observation, researchers also conducted direct interviews with key informants consisting of tandhe', midfielder, buffer tandhe' usual nyawer, and host invites tandhe'. In addition to key informants, interviews were also conducted with Madurese culturalists, in this case Edy Setiawan living in Sumenep District, an academic from the Trunojoyo Madura University in Bangkalan and the religious leaders represented by KH. Safraji, Chairman of the Majelis Ulama Indonesia Indonesian (Indonesian Ulama Council/MUI) of Sumenep Regency, East Java. 
The data collected in the field through observation and interviews to various sources, then conducted a re-check, by verifying other informants who also became parties directly related to tandhe' culture. Data obtained then compiled using data processing techniques, reduce data, present data already obtained. Then described in the form of scientific paper, as presented today. The last is to draw conclusions from the exposure that has been described.

\section{Islam and Culture}

According to Shaykh Mahmûd Syaltut, Islam is the religion of God that is commanded to teach its subjects and regulations to Prophet Muhammad, and commissioned to assign the religion to all human beings, and invites them to embrace it. ${ }^{7}$ Meanwhile, according to A. Gaffar Ismail, Islam is the name of religion brought by Prophet Muhammad contains the completeness of the lessons include beliefs, ceremonies, disciplines of private life, discipline of life, the rules of God, the main building character, and explains the secrets of the second life (hereafter). ${ }^{8}$

According to Koentjaraningrat, culture means the whole of human ideas and works, which he familiarizes with learning, along with the whole of his mind and work. In English terms comes from the Latin word "colere" meaning "to process, to do," especially to cultivate the soil or to farm. From this meaning develops the meaning of "culture" as all human power and effort to change nature. Thus, it is understandable why the concept of culture is so wide in scope, so as to be unrestricted. ${ }^{9}$

According to Haviland, there are three distinctive features of culture. First, culture is a common property. Culture in deeds that can be understood and supported by all members. Because the culture belongs to the collective, so that not a few necessities of life always swirl to the group. They in collective culture want to find the characteristics of the equation in order to adapt easily, so that life is sustainable and growing. Second, culture is the result of learning. All cultures are learning outcomes, not biological inheritance. The process of cultural forwarding from generation to generation follows through the process of enculturation. Third, culture is based on symbols. Leslie White does suggest that all human behavior uses symbols. That is why each that emblematic in human life can be categorized culture. It is the presence of these symbols that always invite different interpretations in cultural studies. From the aspect of substance, there is a tremendous advantage with the presence of the symbol, because it will create a rich culture of meaning. Culture is like a well will never run out for be taken. ${ }^{10}$

${ }^{7}$ Endang Saifuddin Anshari, Wawasan Islam (Jakarta: Gema Insani Press, 2004) p. 40. ${ }^{8}$ Ibid, h. 41.

${ }^{9}$ Koentjaraningrat, Kebudayaan, Mentalitas dan Pembangunan (Jakarta: Gramedia Pustaka Utama, 2004), p. 9-10.

${ }^{10}$ Suwardi Endraswara, Metode, Teori, Teknik Penelitian Kebudayaan (Yogyakarta: Pustaka Widyatama, 2006), p. 27-28. 
Clifford Geertz, interpreting culture in Indonesia with a cultural analysis that calls the occurrence with economic and political interests, such as the Neo-feudalism in economics, politics, and culture so that democracy is lived with feudal and paternalistic spirit. Cultural transformation resulted in a cultural involution, in which feudal and modern dualism constantly constrains the process of cultural and value integration. ${ }^{11}$

According Triyanto, Indonesia has a rich and diverse cultural richness. This diversity or cultural uniqueness is a necessity as a nation state inhabited by many different ethnic groups or ethnic groups. This condition, of course, causes its artistic potential to be bhineka (various but in one unity) in its various forms and manifestations. Art as an element of culture, always influenced and even the expression of culture itself. In empirical life, the arts of the archipelago are generally integrated in the activities of ritual or religious traditions of society. Citizens who are involved as artists, often do not realize that they are doing art. On the contrary, they realize that they are doing their traditional life activities. ${ }^{12}$

\section{Islam, Local Culture, and Tandhe' Culture}

According to Hildred Geertz, in Indonesia today there are over 300 of the tribes who speak in 250 different languages and have different local cultural characteristics. Indonesia region has different geographic and climate conditions. For example, Java's tropical coastal areas to the mountainous region of Jayawijaya in the snowy province of Papua. The differences in climate and geographical conditions affect the local cultural pluralism in Indonesia. ${ }^{13}$ The same thing was delivered by J.W. Ajawaila, who mentioned that the local culture is the original culture of a certain group of people that also characterizes the culture of a local community group. ${ }^{14}$

According to Nur Syam, islamic studies and societies using social construction conceptions produce an additional typology, although in fact it is in the acculturative Islamic category following the views of woodward and his syncretism friends and Islam as Geertz and his friends, is a "collaborative Islam," a link between Islam and a culturallyacculturated-syncretism culture as a result of joint construction between agents (local elites) and society in a continuous process of dialectics. The characteristics of collaborative Islam are typical Islamic buildings, adopting local elements that are not contradictory to Islam and reinforcing the teachings of Islam through a process of continuous transformation

\footnotetext{
${ }^{11}$ Sutrisno and Putranto, Teori-Teori Kebudayaan (Yogyakarta: Kanisius, 2005), p. 71.

${ }^{12}$ Triyanto, "Estetika Nusantara: Sebuah Perspektif Budaya," in Imajinasi, Vol. 4, 2008, p. 1-14.

${ }^{13}$ Hildred Geertz, Aneka Budaya dan Komunitas di Indonesia (Jakarta: Yayasan Ilmu-Ilmu Sosial dan FIS-UI, 1981), p. 7.

${ }^{14}$ R. Soekmono, Pengantar Sejarah Kebudayaan Indonesia I (Yogyakarta: Kanisius, 1998), p. 14.
} 
by legitimizing them based on Islamic texts understood on the basis of the interpretation of local elites. Transformation is done through various mediums resulting in social construction of local Islam. ${ }^{15}$

As for Mahmud Arif, with a pluralistic social-cultural reality, Islamic education should be willing to adopt a critical, dynamic and rational "hermeneutical" approach to appreciating the renewal and uniqueness of local culture, in order to remain able to maintain its sociological relevance. ${ }^{16}$

According to Masyhur Abadi, the culture in Madura, especially the culture in Sumenep is the result of long and continuous process of diffusion, acculturation, and assimilation from various cultures that come from various racial/ethnic communities inhabited. This process of cultural assimilation proceeds naturally as a natural consequence of intercommunity interactions in meeting their needs and life expectancy. In the long blending that produced this multicultural society, Sumenep culture emerged with a unique characteristic as a cultural entity of Sumenep. Non-Sumenep/Madura cultural elements remain visible, but as a cultural entity it has become a culture of Sumenep, cross marriage is one of the institutions which is the factor in which the multi ethnic/racial mixing process goes naturally with the intensity high and total. ${ }^{17}$

Tandhe' is another term of sinden. In Madura, the tandhe' includes the category of local culture in Madura. The slogan culture in Madura does not stand alone, but it is always accompanied by saronen music which is also known as the traditional music of Madura. The tandhe' culture in Madura is familiar with rural communities, while the tandem in urban areas is rare, or even never shown. Regular tandhe' shows at wedding or sapesonok (cow beauty contest).

A tandem (sinden) played an important role in the event. In addition to being a singer and guest entertainer, but the tandhe' also accompanied each guest who was "nandeng" or dancing, from those who were dancing this tandhe' received the saweran. The tandhe' will generally approach the group of male guests who have created the group by sitting circularly and the tandem will invite guests who want to pick up on the stage that has been provided alternately with other groups.

In addition to the tandem, it can be said that there is no other traditional art in Madura where women become the dominant element, women become the determinants and their pencils from start to finish. In fact, the mention of a tandem for the name of art indicates this. The term tandhe' refers more to female dancers. But because he is the most important element, the art itself is ultimately called the tandhe'. A group of men are jogging on stage or in the open ground around a tander or more. For his services, the tandem receives sheets

\footnotetext{
${ }^{15}$ Nur Syam, Islam Pesisir (Yogyakarya: LKiS, 2005), p. 291-292.

${ }^{16}$ Mahmud Arif, Pendidikan Islam Transformatif (Yogyakarya: LKiS, 2008), p. 247.

${ }^{17}$ Masyhur Abadi, "Cross Marriage: Sebuah Model Pembauran Budaya," in Karsa: Journal of Social and Islamic Culture, Vol. XII, No. 2, 2007, p. 149-160.
} 
of money from men who are jogging (saweran). The presence of a tandem on the stage is intentionally invited to enliven the celebration. This social concept is understood as a relief by the Madurese. Currently the tandhe' is more like a professional job, Madura people call it alako (work).

Earnings above average, make them able to take over the role of leadership and family decision makers. This is experienced by Suhadiyah, a tande' from Dasuk, Sumenep, who is capable of fulfilling all the needs of the family because of working as a tandan. He claimed he did not ask for money to her husband, earning an average of Rp 500.000,- to Rp 750.000,- per stage, not including the money amounted to a fantastic amount from one million to three million rupiah. In fact, often the government apparatus and protégé held the event, solicit donations. The donation request also comes from the mosque, boarding school or madrasah. ${ }^{18}$

In addition to having a positive side of income is quite large, but tandhe' also often get a negative view of various circles, because it can dipolek or touched for those who gave saweran. In fact there are naughty by giving saweran in the chest tandhe' by inserting it in the sensitive women. Even in certain cases sometimes touch and wipe the part of womanhood that includes not polite to be done by men to women who are not family. Tandhe' used to wear rape (sort of kemben) and practice nyompeng (giving money in the tandak chest). Tandhe' Madura further highlight the vocal aspects of the dance movement, but now there are also often wearing kebaya like the women of PKK. Moreover, if in the sapesonok contest, clothing tandhe' already very casual, wearing regular shirts and jeans.

\section{Marriage in Islam}

The word marriage comes from Arabic nikâhun which is mashdar or the original word of the word nakaha. The synonym of tazawwaja is then translated into Indonesian as it is called marriage. While in the language, the word marriage means al-dhammu wa al-tadakhul (masked and inserted) therefore according to Arab customs, the clumping of tree clumps like bamboo trees due to the wind blowing is termed tanakahatilasyjar (the grove of the tree is being married), because the wind is friction and the inclusion of one clump to another. Marriage which in term is called "marriage" is a contract or agreement to bond between a man and woman to justify the sexual relationship between the two parties to create a family life that is filled with a sense of affection and tranquility (mawaddah wa rahmah) with ways that are accepted by Allah. ${ }^{19}$

Marriage is a covenant between men and women, in which case marriage is a sacred and powerful agreement (mitsâqan ghalidza) to form an eternal and happy family.

\footnotetext{
${ }^{18}$ Iskandar Zulkarnaen, "Perempuan Tandak dalam Masyarakat Madura," in http://kabarmadura. blogspot.co.id, Monday, August 27, 2007.

${ }^{19}$ Soemiyati, Hukum Perkawinan Islam dan Undang-undang Perkawinan (Yogyakarta: Liberty, 1989), p. 9.
} 
In fact, in the eyes of society, the marriage aims to build, nurture and maintain a harmonious and peaceful kinship, reuniting distant families, as well as silaturrahim. As already hinted at in the Qur'an letter of al-Rûm/30: 21. Thus, marriage to man is not merely copulation between different sexes, but to form a happy and eternal family.

\section{Wedding in Madura}

According to Munawara, Madura is still renowned as a strong society against the culture and customs of the ancestors. One of the cultures that existed since the time of the ancestors and lasted until now even become a legal law that is legalized early marriage. The position of women in early marriage is as a person chosen, appointed, and married, without the right to refuse or consider. The rights of girls since birth have been directed by parents, even in the education field, a girl is considered unimportant, so women feel they have no right to freedom whatsoever. ${ }^{20}$

The marriage in Madura either married off their children in an early, married, or other way is very strong with religious values, in this case Islam, as a religion held by the majority of Madurese. The Islamic tradition of Madurese society is closer to the organization of Nahdlatul Ulama, although it cannot be denied that there are other Islamic organizations such as Muhammadiyah. But in general Madurese society influenced more tradition and culture Nahdlatul Ulama.

This is possible; because most of the Muslim communities in Madura interact more with pesantren whose religious leaders are Nahdlatul Ulama background. Starting from childhood to adulthood and becoming a parent, almost always they interact with religious leaders from the Nahdlatul Ulama, especially in the affairs of marriage.

\section{Theory of Social Integration}

Big Indonesian dictionary defines "integration" as assimilation to become unity The word "unity" implies that different elements are different from each other through the process of assimilation. If an update has reached an association, then the symptom of this change is called integration. In English, integration, among others, means whole or perfection. ${ }^{21}$

The theory of social integration was first coined by Emile Durkheim. Durkheim, wanted to show that how social forces influence human behavior. Then he did research on the suicidal behavior perpetrated by some European countries. Durkheim identifies social integration, the degree of human attachment to the social group. ${ }^{22}$

\footnotetext{
${ }^{20}$ Munawara, et al. "Budaya Pernikahan Dini terhadap Kesetaraan Gender Masyarakat Madura," in Jurnal Ilmu Sosial dan Ilmu Politik, Vol. 4, No. 3, 2015, p. 426-431.

${ }^{21}$ Eka Hendry Ar, "Integrasi Sosial dalam Masyarakat Multi Etnik," in Walisongo: Jurnal Penelitian Sosial Keagamaan, Vol. 21, No. 1, 2013, p. 198.
} 
Myron Weiner, explains that social integration refers more to the process of bringing together different cultural and social groups into a single territory, and a national identity. In such contexts integration refers to the issue of development, a sense of nationality within a particular region in various roles and functions. Integration can also point to the issue of central government authority and power and smaller units, or smaller political territories that may be composed of a particular social cultural group. ${ }^{23}$

According to Nasikun, an integrated social system is based on two things: a society is always integrated on the growing consensus among the majority of society's members of universal social values and integrated society as well as various members of society as well as members of various functioning social unions neutralize the conflicts that result from the existence of dual loyalty. ${ }^{24}$

\section{Tandhe' Culture in Madura}

Culture and Madura art that still exist until the day is tandhe'. Tandhe' by the Madurese community is understood in two ways, first an art of traditional madura singing in which there is najhege (a set of traditional musical instruments), gelandheng (occasional singing guide) and sinden (or also called tandhe'). The second is a traditional female singer or sinden whose position as the sole perpetrator of the arts.

Tandhe' show does not recognize the season and certain times as other arts execution. Tandhe' is often carried out by the Madurese at the reception of an engagement or marriage ceremony. Then tandhe' can be prepared by individuals and community groups. Preparations prepared by community groups are usually in the village (selamatan/rokat). According to Edy Setiawan Budayawan Madura, originally tandhe' (if in Java is commonly referred to as sinden) is a cultural and art of the royal palace in the past, which is usually exhibited and displayed in the kingdom held ceremonial and party activities. In such activities tandhe' presented as a form of entertainment for the royal family, as well as for the audience who came to the event held by the kingdom. In its development, the royal family there are special lifting players tandhe' who become subscriptions to entertain in the events and events held in the palace. Thus, there is a kind of pride for the players and family tandhe' because they are the people who are familiar with the palace and the kingdom. During this time not just anyone can enter the palace and appear in front of the royal family. Especially since the tandhe' player is considered to have its own place among the royal family.

\footnotetext{
${ }^{22} J a m e s$ M. Henslin, Sosiologi dengan Pendekatan Membumi (Jakarta: Erlangga, 2007), p. 8.

${ }^{23}$ Depdikbud, Dinamika Interaksi Sosial dan Integrasi Budaya Antara Komunitas Migran dan Lokal di Distrik Wanggar Kabupaten Nabire Provinsi Papua (Jayapura: Balai Pelestarian Nilai Budaya Jayapura, 2013), p. 39.

${ }^{24}$ Nasikun, Sistem Sosial Indonesia (Jakarta: Rajawali Press, 1988), p. 64.
} 
Along with the royal palace in Madura, tandhe' culture is still sustainable in the life of Madurese society, in the form of performances and performances on ceremonial activities such as weddings, sapesonok, selamatan village, sea salvas and others. The existence of tandhe' as said by the lecturer of FISIP Universitas Trunojoyo, Dinara Maya Julijanti said that tandhe' is a tradition in Madurese society that cannot be eliminated even though there is a negative side of the show such as sawer who want to show the level of class or status that mengwer or invite. The tandhe' art tradition will remain sustainable.

The sustainability of tandhe' art is also conveyed by the West Banuaju Village Chief of Sumenep Regency who once held a tandhe' in 2016, that tandhe' will continue while the engagement or marriage ceremony still exists. This means that tandhe' is often performed in engagement and marriage receptions. Especially today tandhe' does not provide a high cost burden that free to the host. The host simply pays the cost of the music device and provides a place and seeks the number of guests. Tandhe' will take advantage of saweran both from host or invited guests.

According to Edy Setiawan's statement, in Madurese society, especially those living in rural areas, marriage activities can hardly be separated from tandhe'. It can even be called, where there is a wedding party there is a tandhe'. This is common in the Madura region, especially in coastal and pantura areas, such as Batang-Batang, BatuPutih, Dungkek, and others.

While in the terminology of tandhe' art of religion is contrary to Islam. About tandhe' judgment and religion delivered by KH. Safraji, Chairman of the Indonesian Ulema Council of Sumenep regency, that tandhe' in Madura but is considered a culture that is contrary to Islam, because in art and culture tandhe' many practices that are not in accordance with Islamic teachings. Like the existence of men who wear clothing and women's clothing when a tandhe'. Men who resemble women in dressing preening are forbidden, and vice versa. Even if women who become a tandhe' also still not justified, because the act of dancing in public mixed with men, especially there are men who dance with women, not in line with the teachings of Islam. Tandhe' in Religion of Islam is an art that is not justified.

In the midst of the tandhe' incapacity in Islam, tandhe' art continues to be sustainable in the midst of a predominantly Muslim society. Even about the level of one's humanity, many invite tandhe' also from religious and religious circles. Like tandhe' art performed in the engagement of Ananda Zahro Putera Ustad Enno, in the village of Banuaju Timur in 2015. Enno is a religious figure in the village that has langgar (small mosque) and students who study every night as well as children who lodge in pesantren. While tandhe' which is carried out in the religious environment is the engagement of Ananda Lilissaroh, Sutomo's daughter, in Banuaju Barat Village Batang-Batang District, Sumenep Regency. In the neighborhood there are langgar, madrasah diniyah and close to madrasah ibtidaiyah and tsanawiyah. Later, Soetomo was in a religious family, his brother-in-law's caretaker and head of the Madrasah foundation, a cousin of his father-in-law community leader and 
MIQOT Vol. XLII No. 1 Januari-Juni 2018

caregiver diniyah, brother of his youngest in-laws as a community figure, his wife as a school teacher and alumni of pesantren as well as several brothers wife and cousin had high education.

\section{Integration of Tandhe' and Marriage}

Tandhe' is often performed in both engagement and marriage receptions from other ceremonial events. The engagement and marriage ceremonies in Madurese are not familiar with seasonal or certain times. A village sometimes in one day, there are three wedding receptions as well as there are also three tandhe' artistic shows. Because as Edy Setiawan said, tandhe' was held to entertain guests in wedding receptions as well as other events.

In addition to often as a guest entertainer event, tandhe' by Madurese society is considered a culture that has a positive side. Dinara Maya Julijanti, a UGM academician, says tandhe' has a high social value and togetherness that continues to exist between the invitees and the invitees, the interlocutors and the community environment. Even further there is a proud or prestige rasp for people who can invite tandhe' in weddings, because it means the event is celebrated on a large scale that can attract the attention of many people. Enliven marriage by inviting tandhe' is a habit of Madurese community and individual pride.

Between tandhe' and marriage are two different things. Tandhe' as outlined in the above sub-subgroup as the traditional art of Madurese, while marriage is the bonding of promises or marriage bonds that are carried out by religious norms, legal norms and social norms. Generally, marriage is interpreted as a sacred religious activity because it is done in accordance with the teachings or religious traditions. In marriage there are recitations of the scriptures, witnesses who are experts in religion in Madura usually witness invite kyai or ustad. So marriage is a religious and religious nuance while tandhe' is the art and culture of Madurese society.

Wedding reception is the most historic community activity can only be done once in the family during his life, the maximum can be implemented twice but only for certain families and have a fairly established economy. While the tandhe' culture became the most entertaining art and interest by the community both old and teenagers. Most people want a historic event to showcase wonderful activities and excitement for your host and invitees. So as to enable the community to perform tandhe' artistry in wedding receptions.

Tandhe' show in the wedding which is the integration between culture and religion as reviewed by Edy Setiawan there are three factors, first, rural communities in Madura still think that tandhe' is an art and culture that used to be held by the royal family in the palace. So there is such a sense of satisfaction and pride if you can display tandhe' in the most historic activities in the family of weddings. Second, the existence of tandhe' at the wedding adds splendor activities held. Because many families who attend and invite who participated dance with tandhe', and some even give money to the player tandhe' (saweran). 
Third, on the side of society also participate in preserving tandhe' culture. Usually if the wedding activities held tandhe', the pengyawer not only men, but many women. In fact, not infrequently, if the men who participated in dance with tandhe', his wife who gave money to players tandhe' (saweran).

Tandhe' art performances' at weddings as said by Sulamar, head of the Banuaju West street boy group, is considered as commonplace. Wedding reception if it wants to be crowded and has many guests then it should invite tandhe' as an attraction. So usually for people who have enough money will invite tandhe' in the wedding reception, even the middle to lower society also feel compelled to invite tandhe' for the sake of entertaining host invitation and happiness. The same phrase is also expressed by sinden/tandhe' from Tanjung, Putri Maharani. He said he was often invited to weddings. But the most is the engagement. In the wedding ceremony tandhe' shows wedding not directly at the same time. Aqad marriage is usually done one or two days before the reception. On the day of reception the bride and groom are only held and tandhe' art is held for a day and night.

If the wedding is the implementation of marriage 'aqad then as said Princess, has never happened simultaneously on the same day between marriage with tandhe' art:

I am often invited in engagement and marriage ceremonies, but I have never found the same counsel in one day. Usually the difference of two to three days. Even there are married three months and then new reception using tandhe' is held. Maybe other sinden ever meet, and I do not know. But I dont think so. If married first after that tandhe'implementation is often held.

The difference of time difference about the implementation of marriage with tandhe' also conveyed by the chairman of Tormotoran Group from Talango Subdistrict. That the execution of marriage and tandhe' is usually different. Marriage can be held before tandhe' event, can be in the previous night or previous days.

To corroborate the reason for the time difference, it is justified by the host's statement as a marriage and tandhe' time schedule organizer. Mr. Suwalki, from Totosan Village who held his event in 2015, said the separation of the implementation was due to the wishes of local penghulu and kiai. Kiai who are invited to marry suggest taking a different time. The other reason was given by Sanusi from Longos Village, marriage and tandhe' are not good if done simultaneously. In the wedding time, there are a number of religious leaders while tandhe' entertainment that many religious leaders do not contribute. It is morally unacceptable. If for example marriage together with pengajian (prayers) is reasonable. Then at least separated the time even if only one day difference.

In the midst of time differences between cultures and religions, people still support the event's sustainability. Even the kiai continue to participate in the activities that take place. The kiai also remain present in the success of weddings and present to honor tandhe' event. Chairman of the MUI of Sumenep Regency stated that religious leaders in Madura 
still want to come to the wedding held by Muslim families in Madura to marry their families, with the notes of marriage ceremony, not held at the same time with the holding of art and culture of tandhe'. The religious leaders or kiai actually do not reject and prohibit the implementation of tandhe' in marriage even though it is against Islam. The religious leaders only expect that the implementation of both must be separated in different times. Between religion and art which does not in line with Islamic should be separated. Religion and culture can go hand in hand when in culture does not conflict with Islamic shariah. But if the contrary cannot be done simultaneously.

Madurese remain fanatical with both. Tandhe' continues to be sustainable and marriage also continues but the time is set aside. People want marriage to keep sacred is supported and prayed by the teacher/kiai but the culture also continues to run as an appreciation of happiness.

The implementation of tandhe' and the marriage in tandem did not cause significant turmoil from a group of disparate societies. Proven tandhe' remains done in the religious environment and even in religious families. The religious leaders also did not strongly reject the continuity of the two traditions. According to Edy Setiawan, religious leaders, kiai and ulama in Madura are moderate and not easy to judge people. Although morally religious tandhe' does not fit, but they do not openly prohibit tandhe' activities at weddings that take place in Islamic shariah. Most kiai only give advice to their close relatives or students that it is not in accordance with Islamic shariah. But to the general public, the kiai and ulama never publicly declare prohibitions or appeals. So that society assumes tandhe' which is held can be tolerated.

However, although kiai and ulama do not openly ban tandhe' shows at the wedding reception a number of kiai and clerics attempt to separate the two. The effort to separate the two is represented by KH's statement. Syafraji, Chairman of MUI of Sumenep Regency, that religious leaders are trying to eliminate tandhe' culture which is considered not Islamic culture with cultural approach as well, awareness of practices that are not in accordance with Islamic values and teachings ranging from the education of Muslim children. That way, the culture is slowly no longer widely practiced clearly, along with the increasing public awareness of education and values in accordance with Islamic teachings.

Strategy with culture balancing is to prevent conflict and change consciously. Parents who still preach tandhe' activities at weddings, do not feel that they are openly judged by religious leaders, but they still feel that what they do is not in line with Islamic values. So slowly the practice of tandhe' in marriage began to decline, especially in urban areas. 


\section{Conclusion}

Islam and culture can walk in harmony not mutually negated, although there are practices from cultures that are inconsistent with Islamic teachings and norms embraced by religious leaders in Madura, still both can walk, with mutual respect, without negation.

Tandhe' culture is still often held at weddings by the Muslim family in Madura, especially in rural and coastal areas, by separated implementation, not at the same time, there is a pause in a matter of days, between the activities of the ceremony with tandhe' show. It could be tandhe' held first, or 'aqad marriage that was held first, after it held tandhe' with a distance of a day or two after the marriage ceremony.

Walking harmony tandhe' culture with the practice of religious rituals in the form of marriage ceremony that was held in Islam in Madura not be separated from the role of religious leaders who prioritize the cultural approach in addressing tandhe' local culture in Madura which is considered not part of Islamic teachings. The approach of religious leaders is more prioritizing the familial approach in giving understanding to the Muslim families who held tandhe'.

Similarly for tandhe' actors also highly appreciate religious leaders such as kiai who attended the marriage ceremony by marrying the bride in an Islamic way, by delaying the show tandhe' not at the same time with the ceremony of the marriage ceremony by the bride.

More research is needed to find out how the tandhe' culture disappears from the urban areas of Madura. Whereas it was originally tandhe' grow and develop in the city area. As is the case in Sumenep regency, tandhe' used to be held in the palace to fill the family entertainment and royal guests.

In addition, there should also be further research on the phenomenon of change from tandhe' which is now dominated by women both young and middle-aged. Whereas when the first time tandhe' there, the players tandhe' is a man who wore female clothing, and chanting poems and songs that resemble a female voice.

\section{References}

Abadi, Masyhur. "Cross Marriage: Sebuah Model Pembauran Budaya," in Karsa: Journal of Social and Islamic Culture, Vol. XII, No. 2, 2007.

Anshari, Endang Saifuddin. Wawasan Islam. Jakarta: Gema Insani Press, 2004.

Ar., Eka Hendry. "Integrasi Sosial dalam Masyarakat Multi Etnik," in Walisongo: Jurnal Penelitian Sosial Keagamaan, Vol. 21, No. 1, 2013.

Arif, Mahmud. Pendidikan Islam Transformatif. Yogyakarya: LKiS, 2008.

Depdikbud. Dinamika Interaksi Sosial dan Integrasi Budaya Antara Komunitas Migran dan Lokal di Distrik Wanggar Kabupaten Nabire Provinsi Papua. Jayapura: Balai Pelestarian 
MIQOT Vol. XLII No. 1 Januari-Juni 2018

Nilai Budaya Jayapura, 2013.

Endraswara, Suwardi. Metode, Teori, Teknik Penelitian Kebudayaan. Yogyakarta: Pustaka Widyatama, 2006.

Geertz, Hildred. Aneka Budaya dan Komunitas di Indonesia. Jakarta: Yayasan Ilmu-Ilmu Sosial dan FIS-UI, 1981.

Henslin, James M. Sosiologi dengan Pendekatan Membumi. Jakarta: Erlangga, 2007.

Juhari, Imam Bonjol. "Ekonomi dan Prestise dalam Budaya Kerapan Sapi di Madura," in Karsa: Journal of Social and Islamic Culture, Vol. 24, No. 2, 2016.

Koentjaraningrat. Beberapa Pokok Antropologi Sosial. Jakarta: Dian Rakyat, 1967.

Koentjaraningrat. Kebudayaan, Mentalitas dan Pembangunan. Jakarta: Gramedia Pustaka Utama, 2004.

Misnadin. "Nilai-Nilai Luhur Budaya dalam Pepatah-Pepatah Madura: Positive Cultural Values of Madurese Proverbs," in Atavisme: Jurnal Ilmiah Kajian Sastra, Vol. 15, No. 1, 2012.

Munawara, et al. "Budaya Pernikahan Dini terhadap Kesetaraan Gender Masyarakat Madura," in Jurnal Ilmu Sosial dan Ilmu Politik, Vol. 4, No. 3, 2015.

Nasikun. Sistem Sosial Indonesia. Jakarta: Rajawali Press, 1988.

Pribadi, Y. "Religious Networks in Madura: Pesantren, Nahdlatul Ulama, and Kiai as the Core of Santri Culture," in al-Jami'ah: Journal of Islamic Studies, Vol. 51, No. 1, 2013.

Soekanto, Seorjono. Sosiologi Suatu Pengantar. Jakarta: RajaGrafindo Persada, 1982.

Soekmono, R. Pengantar Sejarah Kebudayaan Indonesia I. Yogyakarta: Kanisius, 1998.

Soemiyati. Hukum Perkawinan Islam dan Undang-undang Perkawinan. Yogyakarta: Liberty, 1989.

Susanto, Edi. "Kepemimpinan (Kharismatik) Kyai dalam Perspektif Masyarakat Madura," in Karsa: Journal of Social and Islamic Culture, Vol. XI, No. 1, 2007.

Sutrisno, \& Putranto. Teori-Teori Kebudayaan. Yogyakarta: Kanisius, 2005.

Syam, Nur. Islam Pesisir. Yogyakarya: LKiS, 2005.

Triyanto. "Estetika Nusantara: Sebuah Perspektif Budaya," in Imajinasi, Vol. 4, 2008.

Zulkarnaen, Iskandar. "Perempuan Tandak dalam Masyarakat Madura," in http://kabarmadura. blogspot.co.id, August 27, 2007. 